\title{
Capitulum and floret phenology in Baccharis aliena (Asteraceae, Astereae)
}

\author{
María Victoria Valtierra ${ }^{1,2}$, Gabriela Speroni ${ }^{1}$ \& José Mauricio Bonifacino ${ }^{1}$
}

\begin{abstract}
Inflorescence and floral phenological studies are a source of valuable knowledge to interpret reproductive mechanisms and phylogenetic hypothesis in plants. We analyzed the morphology and functionality floret stages that are present in pistillate homogamous and functionally staminate heterogamous capitula of the dioecious species Baccharis aliena. Phenological monitoring of both types of capitula was carried out in cultivated plants of B. aliena. Floret phenological stages were defined in homogamous and heterogamous capitula by morphometric analyses, from pre-anthesis until senescence symptoms first appeared. Florets of homogamous and heterogamous capitula presented visual anthesis before functional anthesis was achieved and this feature was transferred to the phenology of capitulum. Anthesis of successive series occurs centripetally during a period of 21 days in the homogamous capitula and 20 days in the heterogamous capitula. The timing and length of heterogamous and homogamous capitula is tightly coordinated and almost identical, a feature that ensures floret interaction between plants and pollinator activities. Understanding of breeding systems in the Astereae subtribe Baccharidinae will most assuredly provide helpful insights towards a better understanding of the evolution of this highly successful group. Key words: Baccharidinae, dioecy, head inflorescence, heterogamous, homogamous, reproductive biology.

\section{Resumen}

Los estudios fenológicos florales y de inflorescencias son una importante fuente de conocimiento para interpretar los mecanismos reproductivos y las hipótesis filogenéticas en plantas. Se analiza la morfología y funcionalidad de los estadios florales presentes en los capítulos homógamos pistilados y en los capítulos heterógamos funcionalmente estaminados de la especie dioica Baccharis aliena. El seguimiento fenológico de ambos tipos de capítulos fue realizado en plantas cultivadas de B. aliena. Se determinaron los estadios fenológicos florales de los capítulos homógamos y heterógamos a partir de análisis morfométricos de las flores desde la pre-antesis hasta los primeros síntomas de senescencia. Las flores de los capítulos homógamos y heterógamos presentan antesis visual previa a la antesis funcional y esta característica se traslada al capítulo. La antesis ocurre de forma centrípeta en las sucesivas series de flores, y tiene una duración de 21 días en el capítulo homógamo y 20 días en el capítulo heterógamo. Los capítulos homógamos y heterógamos coinciden exactamente en tiempo y duración del período de floración, característica que asegura la interacción floral entre las plantas y la actividad de los polinizadores. El conocimiento de los sistemas reproductivos en las Astereae subtribu Baccharidinae contribuye a la interpretación de las estrategias evolutivas de este grupo altamente exitoso.
\end{abstract}

Palabras clave: Baccharidinae, dioecia, capítulo, heterógamo, homógamo, biología reproductiva.

\section{Introduction}

Asteraceae, with ca. 24.000 species is the largest family of flowering plants, and it is distributed around the globe except for Antarctica (Funk et al. 2009). The capitulum is its most conspicuous feature, and it represents the functional reproductive unit (Jeffrey 2009). Florets are arranged in spirals that in most cases exhibit acropetal initiation. All spirals initiate development concurrently, thus determining a circular arrangement of florets, commonly referred to as series (Harris et al. 1991), composed of florets that show a similar degree of development. Several floral traits have evolved in flowering plants to promote outcrossing and prevent selfing (Lloyd \& Webb 1986; Lloyd \& Schoen 1992). Protandry, self-incompatibility, herkogamy and secondary pollen presentation are components of a breeding

\footnotetext{
${ }^{1}$ Universidad de la República, Facultad de Agronomía, Departamento de Biología Vegetal, Lab. Botánica, Garzón 780, CP 12900, Montevideo, Uruguay.

${ }^{2}$ Author for correspondence: mvvaltierra@gmail.com
} 
system (Neal \& Anderson 2005) that have evolved in the capitulum to minimize the effects of selfinterference between florets and thus improve outcrossing (Arshid Shabir et al. 2013). All florets in the capitulum are functional units that determine its overall functionality. The capitulum operates as a single flower and it provides more flexible basis for breeding system evolution than does the single flower (Jeffrey 2009).

Dioecy occurs in 5-6\% of the species and $43 \%$ of families of Angiosperms (Renner 2014). This condition has been interpreted as an extreme evolutionary adaptation to increase outcrossing (Thomson \& Barrett 1981), but other selective pressures have been considered as well, such as resource allocation for male and female functions, sexual selection, seed dispersal, pollination, and predation (Bawa 1980; Thomson \& Brunet 1990).

Baccharis L. is the largest genus in the Astereae, with ca. 400 species, occurring from southern United States to South America in Tierra del Fuego (Giuliano 2001; Barroso \& Bueno 2002; Giuliano \& Freire 2011; Heiden 2013). Most species in Baccharis are morphologically gynodioecious (perfect florets and pistillate florets in different individuals) and functionally dioecious (perfect florets are functionally staminate ones). Most are shrubs, and usually have small capitula. Type of floret (i.e., functionally staminate or pistillate) distribution was a critical character to most 19th and 20th century authors for the genus delimitation. The special emphasis on this character was due to the abundance of species with different types of capitula, especially dioecious species, in the subtribe and their extreme rarity elsewhere in the Astereae (Müller 2006).
Baccharis aliena (Spreng.) Joch. Müll. (Asteraceae: Astereae) is a morphologically gynodioecious and functionally dioecious shrub from southern Brazil, central Argentina and eastern Uruguay (Barroso \& Bueno 2002; Deble et al. 2005). The species was considered for a long time as part of Heterothalamus Less., a satellite genus close to Baccharis. However, a broader definition of Baccharis, originally suggested by Nesom $(1988,1993)$ and supported more recently by other authors Giuliano (2001), Müller (2006) resulted in Heterothalamus finally included inside Baccharis (Giuliano \& Freire 2011), an idea that is followed in this paper and corroborated by Heiden \& Pirani (2016) based on a phylogenetic basis.

In Uruguay Baccharis aliena inhabits hilly areas, mainly in Maldonado and Lavalleja departments, where it is a typical component of the vegetation (Valtierra \& Bonifacino 2014). This species has heterogamous and homogamous capitula arranged in corymbiform capitulescences (Fig. 1). The heterogamous capitula are radiate, with pistillate and sterile ray florets, and perfect but functionally staminate (rudimentary ovaries are present) disk florets. The homogamous capitula are radiate and have only pistillate fertile florets (Valtierra \& Bonifacino 2014). In dioecious species, knowledge about both floret and inflorescence phenology help interpreting functionality of each inflorescence, the interactions between staminate and pistillate plants (Ashman \& Schoen 1995; Speroni et al. 2009) and also provide relevant information for phylogenetic analysis. In this context, the objectives of the present study are threefold: 1) to define floret phenological stages, 2) to describe floral phenology and floret presentation
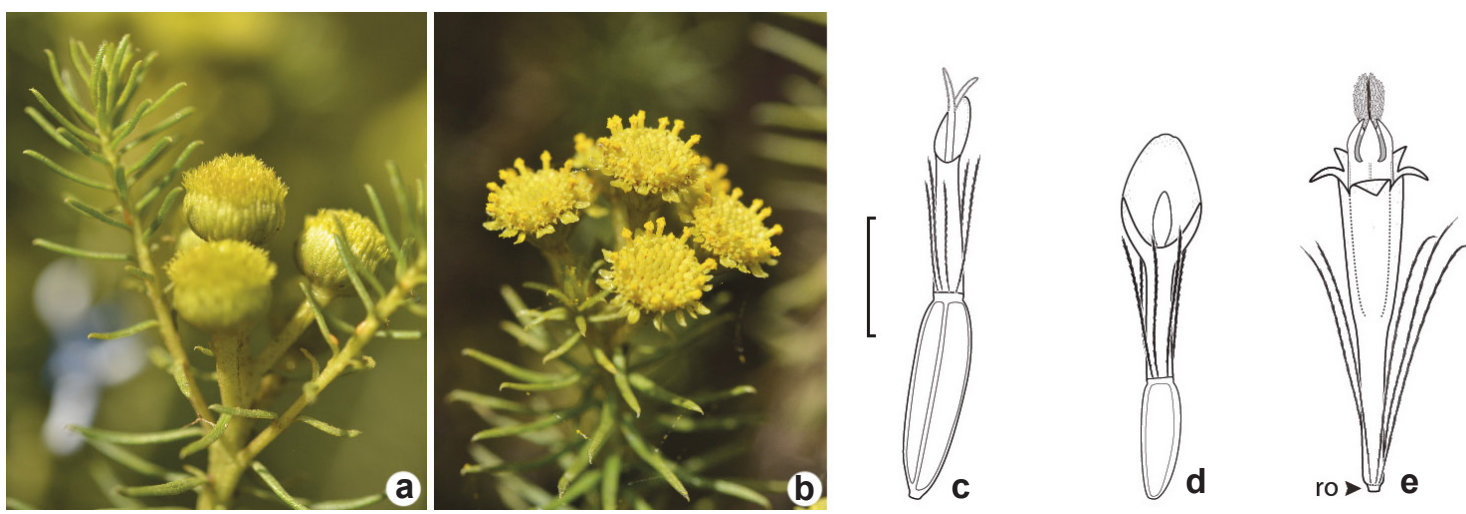

Figure 1 - Capitula and florets of Baccharis aliena - a. homogamous pistillate capitulum; b. heterogamous capitulum; c. pistillate floret of homogamous capitulum; d. pistillate floret of heterogamous capitulum; e. perfect floret with rudimentary ovary from heterogamous capitulum. Legend: ro = rudimentary ovary. Scale bar $=1 \mathrm{~mm}$. 
in B. aliena as a way to characterize homogamous and heterogamous capitula phenology, and 3) to interpret functional interaction between both type of capitula during the flowering period.

\section{Materials and Methods}

Field observations were carried out in cultivated plants at the Botanical Garden of Facultad de Agronomía (Universidad de la República, Uruguay, 3450'14.47''S; 56²'12.93'W), from October $1^{\text {st }}$ up to October $28^{\text {th }}, 2014$. Inflorescence terminology follows Harris et al. (1991). Floret phenological stages (e) were defined in homogamous and heterogamous capitula by morphometric analyses performed under a dissecting microscope, from pre-anthesis until senescence symptoms first appeared using the following characters: 1) floret length, 2) openness of corolla, 3) color of corolla, 4) style and style branch position relative to corolla and anther appendages, and 5) secretion visible (the non-committal term secretion is used instead of nectar as no chemical analysis was carried out).
Additionally, anther appendages relative position to corolla and timing of anther dehiscence were used to describe perfect but functionally staminate florets of heterogamous capitula. Forty capitula in pre-anthesis were marked in both staminate and pistillate plants, and capitula phenological stages (E) were defined by the following variables daily recorded: 1) involucre length, 2) number of floret series in pre-anthesis, 3) number of floret series in anthesis, and 4) number of floret series in senescence. Additionally, paleae position in relation to each floret was registered in homogamous capitula too (i.e., paleae longer than corolla, paleae equaling corolla length, paleae shorter than corolla).

\section{Results}

Florets phenological stages

in the homogamous capitula

Capitula have 100 to 220 pistillate florets arranged in ca. 15 series. Six phenological stages were defined, from pre anthesis floret $(\mathrm{e} 0)$ up to

\begin{tabular}{|c|c|c|c|c|c|c|}
\hline & Pre anthesis & Beginning & Anthesis & Anthesis & Anthesis & Senescence \\
\hline Stages & $\mathrm{e} 0$ & e1 & e2 & e3 & e4 & e5 \\
\hline Floret length & $1.2 \mathrm{~mm}$ & $1.5 \mathrm{~mm}$ & $2.2-2.75 \mathrm{~mm}$ & $2.35-2.8 \mathrm{~mm}$ & $2.2-3.1 \mathrm{~mm}$ & $2.7-3.0 \mathrm{~mm}$ \\
\hline Corolla opening & $\begin{array}{l}\text { limb margins } \\
\text { closed }\end{array}$ & $\begin{array}{l}\text { limb margins } \\
\text { recurved }\end{array}$ & open & open & open & open \\
\hline Corolla color & green & green & green - yellow & green - yellow & green - yellow & yellow - brown \\
\hline $\begin{array}{l}\text { Style and style } \\
\text { branches position }\end{array}$ & $\begin{array}{l}\text { included in corolla } \\
\text { tube }\end{array}$ & $\begin{array}{l}\text { included in corolla } \\
\text { tube }\end{array}$ & $\begin{array}{l}\text { apex exserted from } \\
\text { corolla tube }\end{array}$ & $\begin{array}{l}\text { style branches } \\
\text { exserted } \\
\text { from corolla tube }\end{array}$ & $\begin{array}{l}\text { style and style } \\
\text { branches exserted } \\
\text { from tube and limb }\end{array}$ & $\begin{array}{c}\text { style branches } \\
\text { exserted } \\
\text { from corolla tube }\end{array}$ \\
\hline $\begin{array}{l}\text { Style branches length } \\
\text { above corolla }\end{array}$ & in & - & $0.3 \mathrm{~mm}$ & $0.6 \mathrm{~mm}$ & $0.9 \mathrm{~mm}$ & $0.5 \mathrm{~mm}$ \\
\hline Style branches status & - & - & appressed & $\begin{array}{l}\text { spreading } \\
\text { starts }\end{array}$ & $\begin{array}{l}\text { spread, } \\
\text { receptive surface } \\
\text { is exposed }\end{array}$ & $\begin{array}{l}\text { dehydrated } \\
\text { and shrinked }\end{array}$ \\
\hline
\end{tabular}

Figure 2 - Floret phenological stages in homogamous capitulum of Baccharis aliena. The gray shaded area indicates the floret surface with secretions. Scale bar $=1 \mathrm{~mm}$. 
senescence floret (e5). Features used to characterize phenological stages are shown in Figure 2.

Stage e0: Pre-anthesis. Closed green corolla with close limb margins and curved apex.

Stage e1: Beginning of anthesis. Limb margins recurved, style and style branches included in corolla tube.

Stage e2: Anthesis. Corolla green-yellow, closed style branches with their apex exserted from corolla tube.

Stage e3: Anthesis. Style branches are totally exserted from corolla tube and begin to spread. In e2 and e3 stages, corolla is visually attractive for pollinators but florets are not functionally reproductive yet, because style branches are appressed and their stigmatic surfaces are not yet exposed. These stages (e2 and e 3 ) were defined as visual anthesis.

Stage e4: Anthesis. Style and style branches are totally exserted from corolla tube and limb, style branches are spread and stigmatic surfaces are exposed. Florets are functionally reproductive and this stage was defined as functional anthesis. Secretion is present on corollas' surfaces at the base of the limb.
Stage e5: Senescence. Yellow-brown corolla, style branches are shrank and dehydrated.

Functional anthesis progresses centripetally in successive series during approximately 17 days until senescence symptoms first appear (Fig. 3).

Homogamous capitula phenology

Six phenological stages were defined, from pre anthesis capitulum (E0) to senescent capitulum (E5). Capitulum longevity was 25 days. (Figs. 3 and 4).

Stage E0: Pre anthesis. All florets are subtended by paleae that are longer than the florets at this stage. The seven outer series have florets in e2 stage, the next five or four series have florets in e1, and the most internal series in e0. E0 lasted three days.

Stage E1: Beginning of anthesis. In the seven outer series the florets elongate past subtending palea, and are in e2 stage. Inner series' florets stay as in E0. E1 lasted four days.

Stage E2: Anthesis. Every floret of the capitulum elongate past subtending palea. The seven outer series show florets in stages e4 and

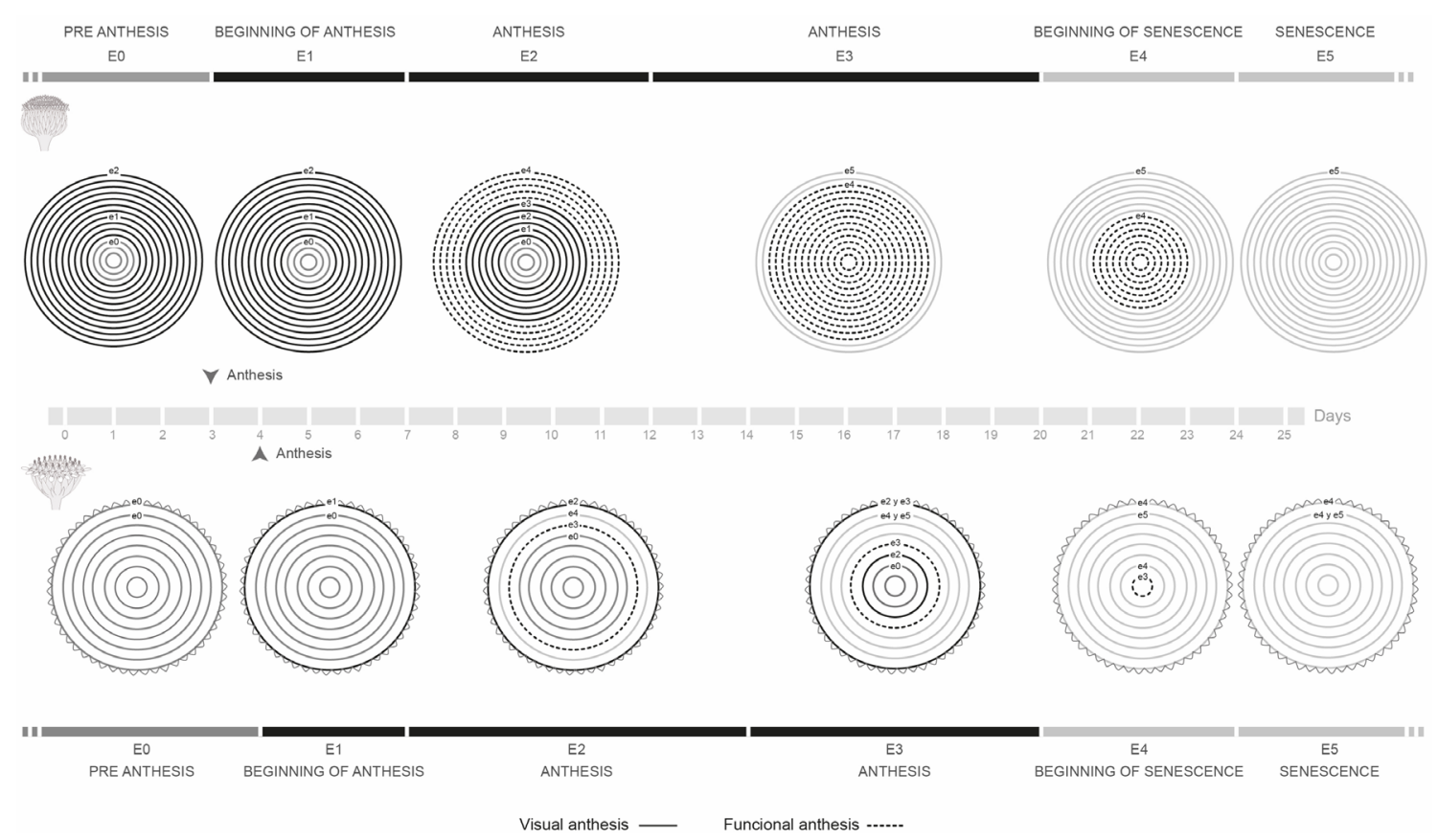

Figure 3 - Capitula phenology of Baccharis aliena. The concentric circles represent the different series of capitulum florets. The dark gray lines represent the series of pre anthesis florets, dotted black lines series of anthesis florets, and light gray lines series of senescent florets. In the top of the figure is represent the homogamous capitulum and in the bottom is represent the heterogamous capitulum. 

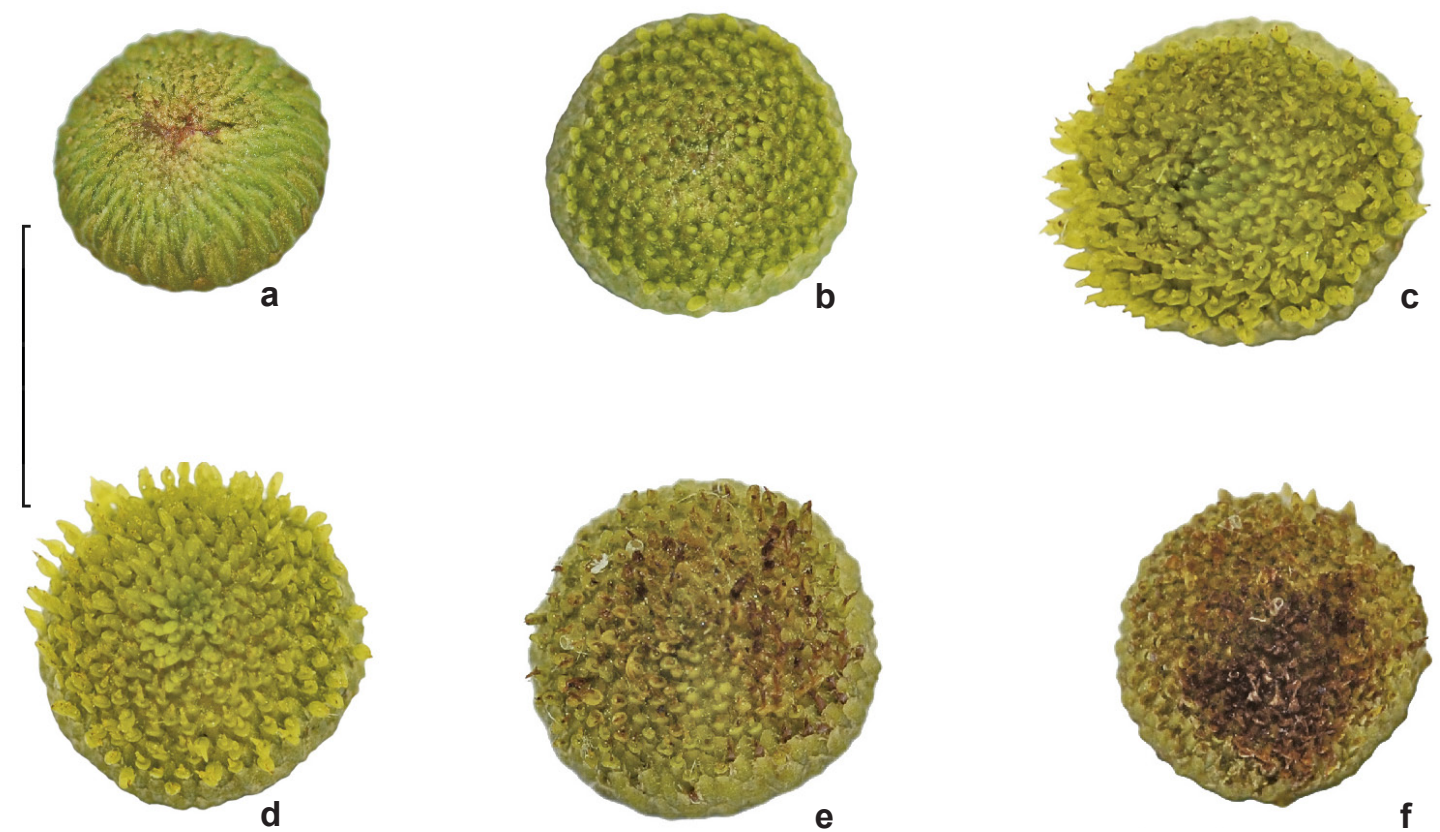

Figure 4-Homogamous capitulum phenology of Baccharis aliena - a. E0: pre anthesis capitulum; b. E1: beginning of anthesis; c. E2: anthesis; d. E3: anthesis; e. E4: beginning of senescence; f. E5: senescence. Scale bar $=5 \mathrm{~mm}$.

e3. Inner series' florets are in stages e2, e1 and e 0 . E2 lasted five days.

Stage E3: Anthesis. Almost all series of florets are in stage e4. First symptoms of senescence in the outer series (with stage e5 florets) are noted. E3 lasted eight days.

Stage E4: Beginning of senescence. More than half of the outer series have senescent florets (e5), and the internal series have florets in anthesis (e4). E3 lasted eight days.

Stage E5: Senescence. All series in the capitulum have senescent florets (e5). E5 was registered after the 24th day of observation.

During homogamous capitula development, a significant increment in the receptacle height was registered. In E1 stage the height is $1.2 \mathrm{~mm}$ and in E4 stage it reaches $1.6 \mathrm{~mm}$.

\section{Floret phenological stages}

in heterogamous capitula

Capitula have 15 to 26 ray florets, arranged in 1 series, and 50 to 90 disk florets in ca. 7 series. Five phenological stages were defined for ray pistillate florets and six for disk perfect and functionally staminate florets, from pre anthesis (e0) up to senescence (e4 in pistillate florets, e5 in perfect florets). Features used to characterize phenological stages are shown in Figure 5.
Ray florets, pistillate and sterile

Stage e0. Pre anthesis. Unopened green corolla with close limb margins and curved apex.

Stage e1. Beginning of Anthesis. Limb in vertical position with spread margins, style branches appressed with $50 \%$ of their length exserted from corolla tube.

Stage e2. Anthesis. Green-yellow corolla, limb at $75^{\circ}$ from the vertical position, style branches appressed with almost all of their length exserted from the corolla tube. Secretion is present on corollas' surfaces at the base of the limb.

Stage e3. Anthesis. Yellow corolla, style branches appressed, all of their length and the apical portion of the style exserted from corolla tube. Secretion is present on corolla surfaces at the base of the limb.

Stage e4. Senescence. Yellow corolla, brown style, dehydrated, and senescent branches, with yellow corollas becoming dehydrated. Absence of secretion.

\section{Disk florets, perfect and functionally staminate}

Stage e0. Pre anthesis. Unopened corollas, green-yellow less developed central Disk florets, and the external Disk florets are yellow and closer to the anthesis. 


\section{Ray florets}

\begin{tabular}{|c|c|c|c|c|c|}
\hline & Pre anthesis & $\begin{array}{l}\text { Beginning } \\
\text { of anthesis }\end{array}$ & Anthesis & Anthesis & Senescence \\
\hline Stages & $\mathrm{e} 0$ & e1 & e2 & e3 & e4 \\
\hline Floret length & $1.2-1.4 \mathrm{~mm}$ & $1.6-1.8 \mathrm{~mm}$ & $2-3 \mathrm{~mm}$ & $3-3.7 \mathrm{~mm}$ & $3-3.7 \mathrm{~mm}$ \\
\hline Corolla opening & closed & opening start & open & open & open \\
\hline Limb posiion & $\begin{array}{l}\text { vertical / close limb } \\
\text { margins }\end{array}$ & $\begin{array}{l}\text { vertical / unfolded } \\
\text { margins }\end{array}$ & ca. $75^{\circ}$ from vertical & ca. $75^{\circ}$ from vertical & ca. $75^{\circ}$ from vertical \\
\hline Corolla color & green & green & yellow - green & yellow & yellow \\
\hline $\begin{array}{l}\text { Style and style } \\
\text { branches position }\end{array}$ & included & $\begin{array}{l}\text { exserted from corolla } \\
0-0.3 \mathrm{~mm}\end{array}$ & $\begin{array}{l}\text { exserted from corolla } \\
0.4 \mathrm{~mm}\end{array}$ & $\begin{array}{l}\text { exserted from corolla } \\
0.6 \mathrm{~mm}\end{array}$ & $\begin{array}{c}\text { exserted from corolla } \\
0.5 \mathrm{~mm}\end{array}$ \\
\hline
\end{tabular}

\section{Disk florets}

\section{Pre anthesis

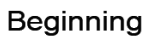 \\ of anthesis}

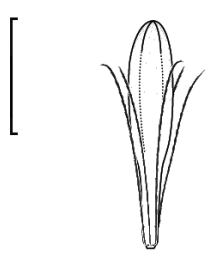

Stages

e0

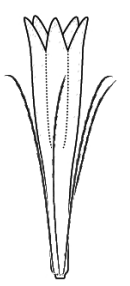

e1
Anthesis

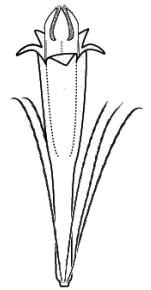

e2

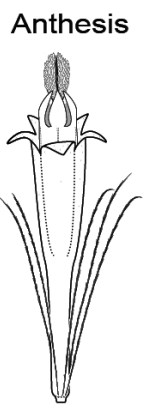

e3

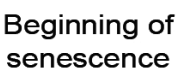

Senescence
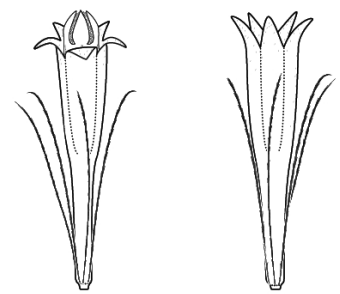

e4

e5

\begin{tabular}{|c|c|c|c|c|c|c|}
\hline Floret length & $1.2-2.5 \mathrm{~mm}$ & $2.3-2.6 \mathrm{~mm}$ & $2.9-3.5 \mathrm{~mm}$ & $2.7-4.5 \mathrm{~mm}$ & $2.7-2.9 \mathrm{~mm}$ & $2.3-2.9 \mathrm{~mm}$ \\
\hline Corolla opening & closed & lobs erects & $\begin{array}{l}\text { lobs horizontally } \\
\text { extended }\end{array}$ & $\begin{array}{l}\text { lobs horizontally } \\
\text { extended }\end{array}$ & $\begin{array}{l}\text { lobs horizontally } \\
\text { extended }\end{array}$ & $\begin{array}{l}\text { lobs erects } \\
\text { dehydrated }\end{array}$ \\
\hline Corolla color & green - yellow & yellow & yellow & yellow & yellow - brown & brown \\
\hline $\begin{array}{l}\text { Anthers } \\
\text { dehiscence }\end{array}$ & - & indehiscent & $\begin{array}{c}\text { dehiscence } \\
\text { beginning }\end{array}$ & dehiscent & dehiscent - dehydrated & dehydrated \\
\hline $\begin{array}{l}\text { Style and style } \\
\text { branches positio }\end{array}$ & n & included & included & $\begin{array}{l}\text { exserted from } \\
\text { anther tube }\end{array}$ & included & included \\
\hline
\end{tabular}

Figure 5 -Floret phenological stages in heterogamous capitulum of Baccharis aliena. The gray shaded area indicates the floret surface with secretions. Scale bar $=1 \mathrm{~mm}$. 
Stage e1. Beginning of anthesis. Open yellow corolla with erect lobes, and in anthers, style and style branches are included in the corolla.

Stage e2. Anthesis. Corolla lobes are horizontally extended, anthers begin anthesis and are exserted from corolla, style and style branches are included in the corolla.

Stage e3. Anthesis. Complete dehiscence, intense yellow pollen covering the internal anther tube, style and style branches exserted from anther tube.

Stage e4. Beginning of senescence. Yellowbrown corolla, anthers are exserted from corolla and becoming dehydrated, senescent style and style branches are again included in the anther tube and corolla.

Stage e5. Senescence. Brown corolla, with erects lobes, senescent anthers included in the corolla with whitish pollen scattered throughout the corolla surface.

\section{Heterogamous capitula phenology}

Six phenological stages were defined, from pre anthesis capitulum (E0) to senescent capitulum (E5). Capitulum longevity was 25 days. (Figs. 3; 6).
Stage E0. Pre anthesis. All series with pre anthesis florets (e0). Disk e0 florets have the typical variations of size and color of the centripetal maturation. E0 lasted four days.

Stage E1. Beginning of anthesis. Ray florets begin the anthesis (e1), Disk florets remain in pre anthesis (e0). E1 lasted four days.

Stage E2. Anthesis. Ray florets in anthesis (e2), with secretion. The external disk florets are in senescence stage (e4),florets in next internal series are in anthesis (e3), and the remaining series are in pre anthesis (e0). E2 lasted seven days.

Stage E3. Anthesis. Ray florets in anthesis (e2 and e3). The three external series of the disk florets are in different senescence stages (e4 and e5), the next two series' florets are in different anthesis stages (e2 and e3), and the remaining series' florets are in pre anthesis (e0). E3 lasted six days.

Stage E4. Beginning of senescence. Senescent ray florets (e4). The five external series of disk florets are senescent (e5), the florets of the remaining seriesare in senescence beginning (e4) and anthesis (e3). E4 lasted four days.

Stage E5. Senescence. Senescent ray florets (e4). Disk florets are in different senescence stages (e4 and e5). E5 was registered after 24 days.
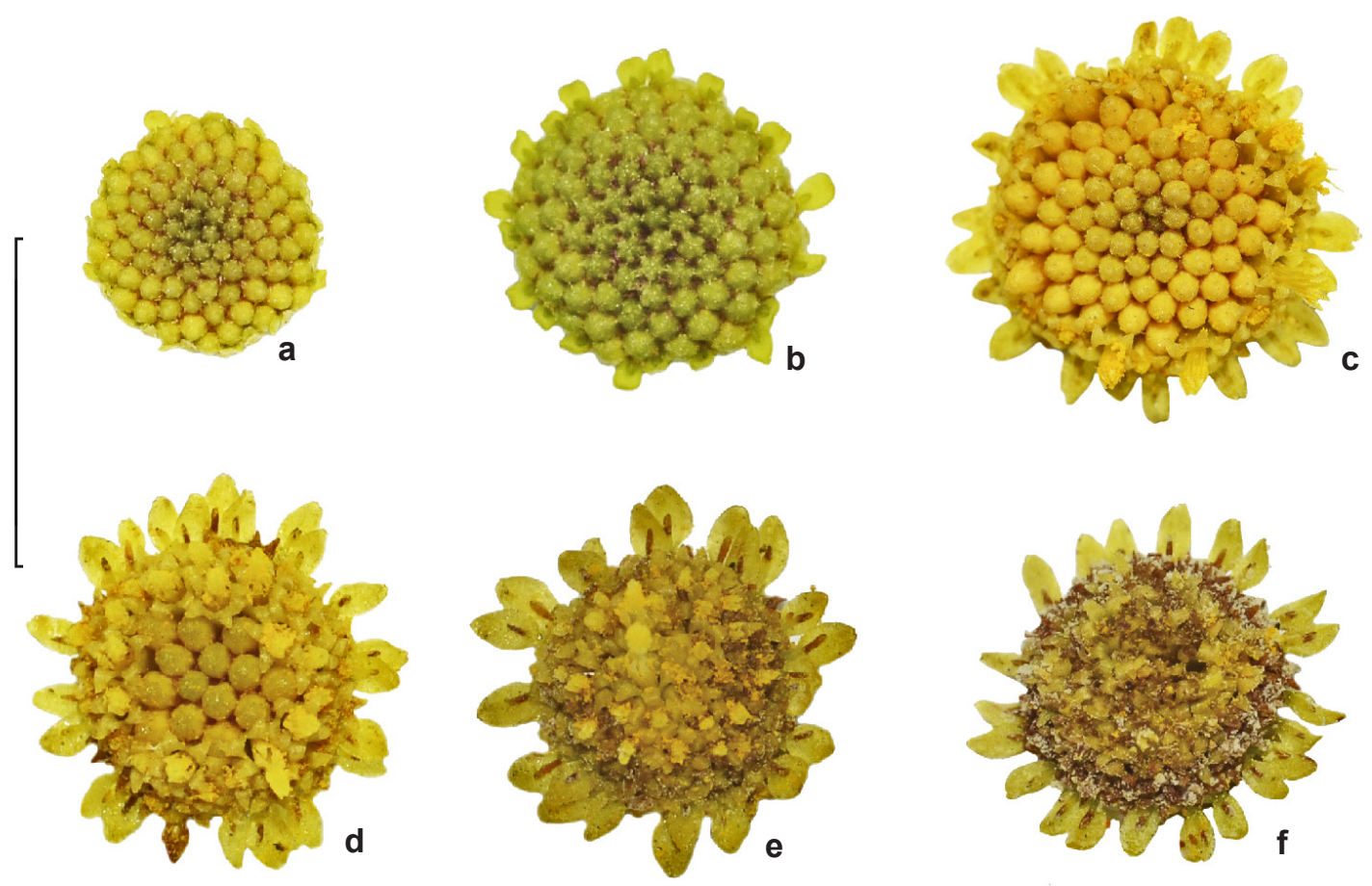

Figure 6-Heterogamous capitulum phenology of Baccharis aliena - a. E0: pre anthesis capitulum; b. E1: beginning of anthesis; c. E2: anthesis; d. E3: anthesis; e. E4: beginning of senescence; f. E5: senescence. Scale bar = $5 \mathrm{~mm}$. 
As seen in homogamous capitula, a significant receptacle height increase was registered during the flowering period. In E1 receptacle height is $0.9 \mathrm{~mm}$ and in E4 and E5 it reaches $1.5 \mathrm{~mm}$.

All capitula develop simultaneously in each plant. Three days after the end of the registered period (October 28th), every capitula of the plant was senescent. The blooming period in both type of capitula in B. aliena is tightly coordinated, both in timing of occurrence and in duration.

\section{Discussion}

Several authors have addressed floret phenological studies (Neff \& Simpson 1990; Cerana 2004; Hong et al. 2008; Huang et al. 2012) or capitulum phenological studies (Brouillet \& Simon 1979; Corral et al. 2004; Bull-Hereñu \& Arroyo 2009), but few researchers have addressed them together (Wild et al. 2003; Wist \& Davis 2006) as in the present study. The anthesis period is defined as the length of time in which individual florets remain open with fresh-looking perianth, pistil and stamens exposed (Primack 1985; Ashman \& Schoen 1995). The anthesis period is a very important phase in the reproductive biology of any Angiosperm, specially in insect-pollinated ones, as it implies interaction with floral visitors and pollen flow processes. Many individual floral adaptations, such as dichogamy/homogamy and herkogamy and heterostyly, promote self- or cross-pollination and determine matches between individuals in this period (Neal \& Anderson 2005), but many other flower features are only displayed to attract pollinators and do not directly determine a mating system. Sometimes, the timing of corolla opening matches that in which pistil and stamens become functional (stigmatic receptivity and anther dehiscence, respectively), but in many flowers, pistil and stamens become functional after anthesis occurs. Therefore, for this latter kind of flower we propose distinguishing between visual anthesis, when corolla opens first and it deploys visual advertising, and functional anthesis, when pistil and/or stamens are functional.

Pistillate florets in the homogamous capitula of B.aliena begin the visual anthesis period when corollas open and color advertising becomes operational. Functional anthesis comes later, when style branches are extended and the receptive surface of stigma is exposed. At this stage, secretion is present on corolla surfaces at the base of the limb, as a potential reward for pollinators. Notwithstanding the fact we did not carry out chemical analyses of the secretion, our observing of several insects feeding on the secretion would favor the hypothesis of the secretion being actually nectar as stated by Vogel (1998).

Several authors (Vogel 1998; Wist \& Davis 2006; Bernardello 2007; Wist \& Davis 2008) have reported nectar production for the Asteraceae. These authors describe secretions coming from the nectary disk present at the base of the style; no report exist to date of nectar secretion coming from other parts of the floret in the Asteraceae. In $B$. aliena the presence of a copious amount of secretion in the whole extent of the corolla could be either an indication of production of this substance on the corolla itself or a result of an overflow of the nectar produced in the disk. Future studies (currently underway) analyzing the anatomy of the florets and monitoring the nectar production throughout the anthesis period will hopefully shed light on this issue.

Each floret in the homogamous capitula of $B$. aliena is subtended by a paleae and pre anthesis of capitulum is defined by all florets yet elongating past the paleae, although florets of outer series have already opened the corollas beneath such paleae. Anthesis of the capitulum starts when florets of outer series emerge of their paleae and open corollas become visible. This is a visual anthesis that acts attracting insects, but florets are not reproductively functional yet. The functional anthesis of the capitulum begins four days after visual anthesis has started and it is defined by the exposure of the stigmatic receptive surface, which is now ready to receive the pollen provided by pollinators. At this time, individual florets attract pollinators and provide rewards by secretions present on the surface of corollas.

Contrasting with the homogamous capitula, florets in the heterogamous ones lack paleae, therefore pistillate sterile ray florets come into anthesis when corolla is open and style branches are exserted from the corolla tube. Style branches remain appressed during floret development, but secretion is still observed on corolla surfaces at the base of the limb. These florets are present in the outer series of the capitulum and act as visual advertising and floral rewards for pollinators, but they don't directly have a reproductive function.

Disk florets are morphologically perfect but functionally staminate. They first come into visual anthesis when actinomorphic corollas open, anther tubes becomes exposed above the corolla, but pollen is not visible yet. Functional 
anthesis takes place right after, when style branches grow, they are exserted from anthter and yellow pollen is exposed on abaxial side of style branches.

Secondary pollen presentation is present in Asteraceae and it involves a pollen relocation mechanism from the anther onto another floral organ, which then functions as the pollen donor organ for pollination (Howell et al. 1993). In functionally perfect florets of Asteraceae, protandry is common and it is hypothesized to be the result of selection to avoid self-fertilization (Arshid Shabir et al. 2013). In Disk florets of Baccharis aliena, pistil has no receptive surfaces and its only function seems to be as a part of the secondary pollen presentation mechanism. Therefore, disk florets of B. aliena present spatial but not functional protandry as defined by Arshid Shabir et al. (2013).

In the heterogamous capitula of B.aliena, pistillate sterile ray florets start anthesis first and begin visual pollinator attraction by color advertising. Zygomorphic corollas have been stated to increase visual attraction in Asteraceae capitula (Lane 1996), although florets of B. aliena also offer nectar as a floral reward. Style branches of these florets never spread, which is consistent with their lacking of functional receptive surfaces. After three days exhibiting only visual anthesis, functionally staminate disk florets begin releasing pollen. Florets of one or two series open simultaneously and anthesis occurs centripetally in successive series during an extended period of almost 17 days. Throughout this time period, pistillate sterile ray florets remain open, which reinforces visual advertising for the capitulum visitors. In these florets, senescence is first manifested on the pistil and later in the corolla, which extends over time the period of corolla visual attraction.

Phenological synchronization was observed between marked capitula of the same plant, so flowering occurs in a concentrated time period in which all capitula are almost at the same functional stage (Fig. 3). Visual anthesis lasts four days in homogamous capitula and three days in heterogamous ones. Thereafter, both types of capitula start a long period of functional anthesis (ca. 17 days), considerably longer than the five to eight days registered in Inula racemosa Hook. f.capitula (Arshid Shabir et al. 2013), and the four to six days recorded in Bidens pilosa var. radiata (Sch. Bip.) J.A. Schmidt (Huang et al. 2012). Reports of the period of functional anthesis for other Baccharis species are lacking to date. As mentioned before, sincronization of blooming period in both type of capitula in B. aliena is tightly coordinated. This feature does not match records for the dioecious Baccharis dracunculifolia DC. in which flowering phenology differed between functionally staminate and pistillate capitula, with staminate plants producing more inflorescences, and earlier, than pistillate ones (Espírito-Santo et al. 2003). Flowering synchronization is very important in a dioecious species, because ensures pollinators' activities and florets interaction between staminate and pistillate plants. Flower synchrony was related in dioecious species to out-crossing and pollinators' attraction rather than climatic factors (Morellato 2004). Species with flowers arranged in inflorescences show an increase in the length of the blooming period, which triggers an increase of staminate and pistillate plants interactions (Wyatt 1982). Some authors (Wyatt 1982; Harris 1995) have interpreted the capitulum as a unit biologically equivalent to a single flower. However, Burtt (1961) stated that this is true only in reference to pollinator attraction because presentation of many single-ovule florets increases outcrossing rates when compared to multi-ovule florets. This latter author called Asteraceae floret organization as "collectivist" and he asserts that the type of inflorescence present in the Asteraceae is a way to extend the flowering period.

Floret's phenology of both types of capitula in B.aliena determine overall functionality in homogamous and heterogamous capitula. A visual period, which attracts floral visitors, precedes a functional period in which pollen flow and its reception occur. This situation (i.e., visual anthesis achieved before functional one) could be a strategy to establish a pollinator community on Baccharis aliena populations before functional anthesis is achieved by means of assuring the arrival of effective pollinators (Ballantyne et al. 2015). This strategy could be a key factor behind reproductive success for a dioecious species that shows a high degree of flowering synchronization between plants as it has been reported in this study.

Floret features observed such as spatial protandry, secondary pollen presentation, floret advertising and the evidence of secretion determine capitula breeding system and promote tight synchronization and outcrossing rates between pistillate and staminate shrubs.

Dioecy in the Astereae is a rather uncommon condition mostly restricted to the Baccharidinae, a monogeneric group formed by the large genus 
Baccharis (Muller 2006). Given the diversity of breeding systems present in this rather complex genus (Nesom 1993; Muller 2006), studies aimed towards a better understanding of such systems will add invaluable information to interpret phylogenetic hypothesis in Baccharis and see how such different reproductive strategies could have both evolved and driven the evolution of this highly successful taxon as a whole.

\section{Acknowledgments}

We thank Programa de Posgrado of Facultad de Agronomía, PEDECIBA (Programa de Desarrollo de las Ciencias Básicas) of Facultad de Ciencias, for financial support and CAP (Comisión Académica de Posgrado de Universidad de la República) for a graduate student fellowship provided to VV. We would also like to thank two anonymous reviewers whose comments and suggestions helped improve this mss.

\section{References}

Arshid Shabir P, Ahmad Nawchoo I \& Ahmad Wani A (2013) Floral phenology, secondary pollen presentation and pollination mechanism in Inula racemosa (Angiosperms: Asteraceae). Journal of Threatened Taxa 5: 4498-4503.

Ashman TL \& Schoen DJ (1995) Floral longevity: fitness consequences and resource costs. In: Lloyd DG \& Barrett SCH (eds.) Floral biology. Studies on floral evolution in animal-pollinated plants. Chapman \& Hall, New York. Pp. 112-139.

Ballantyne G, Baldock KCR \& Willmer PG (2015) Constructing more informative plant-pollinator networks: visitation and pollen deposition networks in a heathland plant community. Proceedings of the Royal Society B 282: 20151130. DOI: <http:// dx.doi.org/10.1098/rspb.2015.1130>.

Barroso GM \& Bueno O (2002) Compostas. 5. Subtribo: Baccharidinae. In: Reitz R (ed.) Flora ilustrada catarinense. Herbário Barbosa Rodrigues, Itajaí. Pp. 765-1065.

Bawa KS (1980) Evolution of dioecy in flowering plants. Annual Review of Ecology and Systematics 11: 15-39.

Bernardello G (2007) A systematic survey of floral nectaries. In: Nicolson SW, Nepi M \& Pacini E (eds.) Nectaries and nectar. Springer, Dordretch. Pp. 19-128.

Brouillet L \& Simon JP (1979) Resource allocation and phenology of two species of Aster (Asteraceae) and their hybrid. Canadian Journal of Botany 57: 1792-1799.

Bull-Hereñu K \& Arroyo MTK (2009) Phenological and morphological differentiation in annual
Chaetanthera moenchioides (Asteraceae) over an aridity gradient. Plant Systematics and Evolution 278: 159-167.

Burtt BL (1961) Compositae and the study of functional evolution. Transactions of the Botanical Society of Edinburgh 39: 16-232.

Cerana MM (2004) Flower morphology and pollination in Mikania (Asteraceae). Flora 199: 168-177.

Corral M, Febles R \& Perez de Pa J (2004) Fenología estacional y del capítulo de la sección Monoptera (Sch. Bip.) Humph. De Argyranthemum Webb ex Sch. Bip. (Asteraceae-Anthemidae) endémica de Gran Canaria. Botánica Macaronésica 25: 127-141.

Deble L, Oliveira A \& Marchiori JN (2005) O gênero Heterothalamus Lessing e taxones afins. Balduinia 1: 1-20.

Espírito-Santo MM, Madeira BG, Neves FS, Faria ML, Fagundes M \& Wilson Fernandes G (2003) Sexual differences in reproductive phenology and their consequences for the demography of Baccharis dracunculifolia (Asteraceae), a dioecious tropical shrub. Annals of Botany 91: 13-19.

Funk VA, Susanna A, Stuessy TF \& Robinson H (2009) Classification of Compositae. In: Funk VA, Susanna A, Stuessy TF \& Bayer RJ (eds.) Systematic, evolution, and biogeography of Asteraceae. International Association for Plant Taxonomy, Vienna. Pp. 171-189.

Giuliano DA (2001) Clasificación infragenérica de las especies Argentinas de Baccharis (Asteraceae, Astereae). Darwiniana 39: 131-154.

Giuliano DA \& Freire SE (2011) Nuevas Secciones en Baccharis (Asteraceae, Astereae) de América del Sur. Annals of the Missouri Botanical Garden 98: 331-347.

Harris EM, Tucker SC \& Urbatsch LE (1991) Floral initiation and early development in Erigeron philadelphicus (Asteraceae). American Journal of Botany 78: 108-121.

Harris EM (1995) Inflorescence and floral ontogeny in Asteraceae: a synthesis of historical and current concepts. Botanical Review 61: 93-278.

Heiden G (2013) Two new combinations in Baccharis (Asteraceae, Asterae). Phytoneuron 78: 1-2.

Heiden G \& Pirani JRP (2016) Novelties towards a phylogenetic infrageneric classification of Baccharis (Asteraceeae: Astereae). Phytotaxa 289: 285-290.

Hong L, Shen H, Ye W, Honglin H \& Wang Z (2008) Secondary pollen presentation and style morphology in the invasive weed Mikania micrantha in South China. Botanical Studies 49: 253-260.

Howell GJ, Slater AT \& Knox RB (1993) Secondary pollen presentation in angiosperms and its biological significance. Australian Journal of Botany 41: 417-438. 
Huang Y, Chen S \& Kao W (2012) Floral biology of Bidens pilosa var. radiata, an invasive plant in Taiwan. Botanical Studies 53: 501-507.

Jeffrey C (2009) Evolution of Asteraceae flowers. In: Funk VA, Susanna A, Stuessy TF \& Bayer RJ (ed.) Systematic, evolution, and biogeography of Asteraceae. International Association for Plant Taxonomy, Vienna. Pp. 131-137.

Lane MA (1996) Pollination biology of Compositae. In: Caligari PDS \& Hind DJN (ed.) Compositae: biology $\&$ utilization. Proceedings of the International Compositae Conference, Royal Botanic Gardens, Kew. Pp. 61-80.

Lloyd DG \& Schoen DJ (1992) Self- and crossfertilization in plants. 1. Functional dimensions. International Journal of Plant Science 153: 358-369.

Lloyd DG \& Webb CJ (1986) The avoidance of interference between the presentation of pollen and stigma in angiosperms. New Zealand Journal of Botany 24: 135-162.

Morellato LPC (2004) Phenology, sex ratio, and spatial distribution among dioecius species of Trichilia (Meliaceae). Plant Biology 6: 491-497.

Müller J (2006) Systematics of Baccharis (CompositaeAstereae) in Bolivia, including an overview of the Genus. Systematic Botany Monographs 76: 1-341.

Neal PR \& Anderson GJ (2005) Are 'mating system' 'breeding system' of inconsistent and confusing terminology in plant reproductive biology or is it the other way around? Plant Systematic and Evolution 250: 173-185.

Neff JL \& Simpson BB (1990) The role of phenology and reward structure in the pollination biology of wild sunflower (Helianthus annuus L., Asteraceae). Israel Journal of Botany 39: 197-216.

Nesom GL (1988) Baccharis sect. Baccharidastrum (Compositae: Astereae), including two monoecious and one dioecious species. Phytologia 65: 169-173.

Nesom GL (1993) Aztecaster (Asteraceae: Astereae), a new ditypic genus of dioecious shrub from Mexico with redefinitions of the subtribes Hinterhuberinae and Baccharidinae. Phytologia 75: 55-73.

Primack RB (1985) Longevity of individual flowers. Annual Review of Ecology and Systematics 16: 15-37.

Renner SS (2014) The relative and absolute frequencies of angiosperm sexual systems: Dioecy, monoecy, gynodioecy, and an updated online database. American Journal of Botany 101: 1588-1596.

Speroni G, Izaguirre P, Bernardello G \& Franco J (2009) Intrafloral phenology of Trifolium polymorphum Poir. (Leguminosae) aerial flowers and reproductive implications. Acta Botanica Brasilica 23: 881-888.

Thomson JD \& Barrett SCH (1981) Selection for outcrossing, sexual selection, and the evolution of dioecy in plants. American Naturalist 3: 443-449.

Thomson JD \& Brunet J (1990) Hypotheses for the evolution of dioecy in seed plants. Trends in Ecology and Evolution 5: 11-16.

Valtierra MV \& Bonifacino JM (2014) Revisión Taxonómica de Baccharis Sect. Heterothalamus (Less.) Giuliano (Asteraceae: Astereae) en Uruguay. Boletín de la Sociedad Argentina de Botánica 49: 613-620.

Vogel S (1998) Remarkable nectaries: structure, ecology, organophyletic perspectives. IV. Miscellaneous cases. Flora 193: 225-248.

Wild JD, Mayer E \& Gottsberger G (2003) Pollination and reproduction of Tussilago farfara (Asteraceae). Botanische Jahrbücher fur Systematik 124: 273-285.

Wist TJ \& Davis AR (2006) Floral nectar production and nectary anatomy and ultrastructure of Echinacea purpurea (Asteraceae). Annals of Botany 97: 177-193

Wist TJ \& Davis AR (2008) Floral structure and dynamics of nectar production in Echinacea pallida var. angustifolia (Asteraceae). International Journal of Plant Sciences 169: 708-722.

Wyatt R (1982) Inflorescence architecture: how flower number, arrangement, and phenology affect pollination and fruit-set. American Journal of Botany 69: 585-594. 
